FROM VICTIMS TO SUSPECTS 


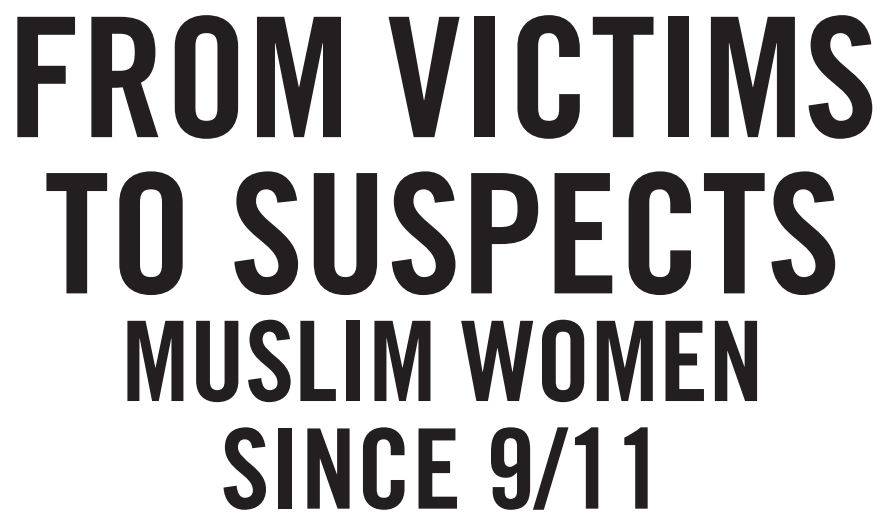

\section{SHAKIRA HUSSEIN}

YALE UNIVERSITY PRESS

NEW HAVEN AND LONDON 
Copyright (C) 2019 Shakira Hussein

First published by NewSouth Publishing 2016

All rights reserved. This book may not be reproduced in whole or in part, in any form (beyond that copying permitted by Sections 107 and 108 of the U.S. Copyright Law and except by reviewers for the public press) without written permission from the publishers.

For information about this and other Yale University Press publications, please contact:

U.S.Office: sales.press@yale.edu yalebooks.com

Europe Office: sales@yaleup.co.uk yalebooks.co.uk

Set in Adobe Caslon Pro by IDSUK (DataConnection) Ltd

Printed in Great Britain by TJ International, Padstow, Cornwall

Library of Congress Control Number: 2018959579

ISBN 978-0-300-23042-0

A catalogue record for this book is available from the British Library.

10987654321 
For my daughter, Adalya Nash Hussein 
